\title{
Krytyczne wydarzenia życiowe i ich znaczenie w biografiach seniorów
}

\begin{abstract}
Abstrakt
Artykuł przedstawia wyniki stanowiące część szerszych badań międzypokoleniowych na temat ważnych, znaczących wydarzeń biograficznych. Narracje osób badanych zostały poddane analizie przez pryzmat wyłonionych w literaturze kryteriów odnoszących się do tzw. krytycznych wydarzeń życiowych (m.in. nagłość zdarzenia i nieprzewidywalności jego skutków, potencjalna dwuwartościowość, rodzaj i charakter zmian życiowych, jakie są efektem zmagania z tym zdarzeniem). Autorki podejmują próbę zrekonstruowania najbardziej typowych krytycznych wydarzeń życiowych i ich znaczenia w biografiach seniorów. Perspektywa temporalna (schyłek życia, czas podsumowań) służy refleksyjnej narracji i czyni ją tym samym wartościową dla egzemplifikacji możliwych (potencjalnych) skutecznych i nieskutecznych strategii życiowych, poczucia jakości życia oraz podstawę budowania mądrości życiowej.
\end{abstract}

Słowa kluczowe: krytyczne wydarzenia życiowe, starość, mądrość życiowa.

\section{Critical Life Events and Their Impact on Seniors' Biographies}

\begin{abstract}
The article presents the preliminary results of a wider intergenerational study on critical life events. A background analysis of theoretical works on critical life events has led to the selection of criteria (such as the unexpectedness of an event, unpredictability of its effects, its equivocation, type and the nature of life changes it
\end{abstract}

\footnotetext{
* Uniwersytet im. A. Mickiewicza w Poznaniu, Wydział Studiów Edukacyjnych.

** Uniwersytet Kazimierza Wielkiego w Bydgoszczy, Wydział Psychologii.
} 
causes) that were used to review the collected narratives of the respondents. The authors attempt to reconstruct critical life events that are the most typical and significant in the biographies of seniors. The seniors' temporal perspective (decline of life, time of summaries) encourages a more reflective narration that unveils the rich exemplification of potential effective and ineffective life strategies, the subjective quality of life, and the basis of life wisdom.

Keywords: critical life events, old age, wisdom.

\section{Wprowadzenie}

W rozważania nad naturą starości wpisana jest kategoria czasu. Jest tak, ponieważ sama starość jako okres/etap w biegu życia człowieka ma swoją czasową chronologię. Porządek zdarzeń oraz ramy czasowe opisujące np. wiek badanej populacji ułatwiają badaczom precyzyjne diagnozowanie m.in. zmian, potrzeb, zasobów. Czas to w tym przypadku Chronos, który jest zewnętrzny, zobiektywizowany (biologiczny i społeczny). Ponadto czas rozumiany zarówno jako tenże Chronos, jak i jako Tempus, czyli czas wewnętrzny, subiektywny (biologiczny, społeczny, psychologiczny) i biograficzny jest swoistym czynnikiem kontroli. Podkreśla ten jego aspekt Piotr K. Oleś:

jeśli postrzegana perspektywa temporalna jest odległa, okazji do zmian będzie jeszcze wiele i dużo można zmienić; jest czas na rozpoczęcie nowych działań lub porzucenie aktualnych, można rozwinąć zdolności, zdobyć kompetencje i wiele osiągnąć. Jeśli perspektywa temporalna postrzegana jest jako krótka, życie, a nawet jego bilans, wydają się przesądzone. Znaczenie wcześniejszych wyborów rośnie i przybiera nieodwracalny charakter, niewiele da się już zmienić. Dlatego to właśnie postrzeganie perspektywy temporalnej stanowi katalizator zmian (Oleś 2011: 60).

Właściwa starości perspektywa temporalna (schyłek życia, czas podsumowań) służy refleksyjnej narracji i czyni ją wartościową dla egzemplifikacji możliwych (potencjalnych) skutecznych i nieskutecznych strategii życiowych. Pozwala przyjrzeć się sposobom realizowania poczucia jakości życia przy biograficznie istotnych, przełomowych zdarzeniach w życiu seniorów. Daje możliwość pozyskania narracji o przeszłości jako cennego źródła wiedzy w międzypokoleniowym procesie uczenia się z biografii Innych (Dubas 2011).

Starość zgodnie z założeniami psychologii biegu życia (life-span psychology) to etap rozwoju, w którym człowiek podejmuje takie zadania, jak: przystosowanie się do spadku sił fizycznych, przystosowanie się do emerytury i zmniejszonych dochodów, pogodzenie się ze śmiercią współmałżonka(i), przyjmowanie i dostosowanie 
się do zmiennych ról społecznych (Havighurst 1972; por.: Oleś 2011: 52). W starości człowiek rozstrzyga finalny konflikt rozwojowy „integracja vs rozpacz” (Erikson 1997). Ponieważ rozpiętość czasowa tej fazy jest bardzo duża i obejmuje tzw. trzeci i czwarty wiek, Beata Bugajska (2015), naśladując pomysł Jane Erikson, rozszerza koncepcję Eriksona do dziewięciu faz. Ostatnim nadal jest kryzys integralność vs rozpacz, ale poprzedza go, adresowany do osób w tzw. trzecim wieku, kryzys fazy ósmej zaangażowanie vs rezygnacja (Bugajska 2015: 29).

Istotna z punktu widzenia niniejszych rozważań jest także konstatacja, że pod względem dynamiki starość nie różni się od pozostałych faz rozwoju człowieka, odmienne są jedynie proporcje między progresem i regresem:

Zmniejszają się możliwości organizmu, a siła oddziaływania na środowisko poprzez pełnione role społeczne zwiększa się. Pamięć i zdolność uczenia się słabną, ale wzrastają wiedza i umiejętności jej wykorzystania. Zmniejsza się energia konieczna do realizowania dążeń (a męczliwość zwiększa), ale motywacja, by zdążyć $\mathrm{z}$ realizacją rzeczy subiektywnie ważnych staje się coraz większa (Oleś 2011: 22).

Wiedza oraz odwaga dokonywania subiektywnie ważnych wyborów łączy się z mądrością życiową, która bywa, nie tylko potocznie, przypisywana ludziom starym. Dodaje ona dostojeństwa, jest specyficznym osiągnięciem rozwojowym i zasobem osób starych w kontekście międzypokoleniowego mentoringu (Konieczna-Woźniak 2015; Kuryś-Szyncel 2017b). Mądrość życiową rozpatruje się z dwóch perspektyw koncepcji intuicyjnych i koncepcji wyartykułowanych/systematycznych. W pierwszym ujęciu posługujemy się wiedzą potoczną, pochodzącą z codziennego obcowania z osobami powszechnie uznawanymi za mądre. Mądry zatem to ten, kto rozumie istotę/sens życia; wie kiedy i jak udzielać rad; jest świadomy dynamiki/polifonii życia; jest „ludzki”. Z kolei w ujęciu „naukowym” mądrość życiowa może być rozumiana zarówno jako: mądrość w odniesieniu do siebie/do „ja” (Staudinger, Dörner, Mickler 2005) oraz cecha osobista (Erikson 1959; McAdams de St. Aubin, Logan 1993) czy własność osoby „autora siebie” (Obuchowski 2000, 2005; Błachnio 2006, 2011; Ożarowski 2011), ale także jako atrybut poznawczy, pewien specjalny rodzaj wiedzy odnoszącej się do życia: system ekspercki/znawstwo w dziedzinie podstawowej pragmatyki życiowej - Berliński Paradygmat Mądrości (Baltes i in. 2004) czy np. wiedza proceduralna używana w sposób twórczy do rozwiązywania problemów życiowych (Pietrasiński 2001, 2008) i efekt myślenia postformalnego (koncepcje neopiagetowskie: Laubovie-Vief 1990).

Zatem badanie polegające na rekonstrukcji zdarzeń biograficznych, które z perspektywy schyłku życia postrzegane są jako ważne i znaczące, ma nie tylko wymiar poznawczy, ale także wymiar edukacyjny - może stanowić materiał do 
uczenia się z biografii Innych (uczenia się z cudzych przypominanych doświadczeń) oraz cenny zasób wiedzy (mądrości życiowej) użytecznej w niełatwej sztuce konstruowania osobistych projektów życiowych przez młodsze pokolenia. Rekonstrukcja ta może przyczynić się do wyłonienia tych wydarzeń biograficznych, które są uniwersalne egzystencjalnie.

Czas biograficzny i dystans, z jakiego seniorzy mogą oglądać bieg własnego życia może sprzyjać wzrostowi liczby tzw. przełomów życiowych. Jednakże nie w ilości tkwi bogactwo doświadczeń, a w ich bilansie. Pozytywny (dodatni) bilans zysków i strat i poczucie wzmocnienia, z jakim człowiek wychodzi z procesu zmagania się z krytycznymi zdarzeniami życiowymi stanowi zasób osobisty i mieści się w kategorii tzw. antecedensów (czynników poprzedzających) ewentualne wystąpienie kolejnych zdarzeń przełomowych. Z kolei ujemny (negatywny) bilans sprawia, że każde kolejne zdarzenie przełomowe w biografii traktowane jest jako zagrożenie dla dalszego rozwoju i może decydować o powstrzymywaniu się przez jednostkę przed dalszym działaniem (Kuryś-Szyncel, 2017a: 50).

To, co i w jaki sposób przeżywają seniorzy kształtuje ich poczucie jakości życia (Błachnio 2017). Kategoria ta w swej naturze polimodalna (Schalock 2004) wyznacza granicę między tym, co akceptowalne wobec tego, co jest odrzucane przez jednostkę w relacji do systemu wartości, preferowanych standardów, celów, obaw, oczekiwań (Gilhooly i in. 2007). Jakość życia zależy od zdrowia fizycznego i psychicznego, autonomii i niezależności jednostki, otoczenia społecznego czy nawet warunków środowiskowych, w których funkcjonuje (Błachnio 2019). Często globalny wskaźnik jakości życia jest addytywną kompilacją wskaźników cząstkowych (Zalewska 2003) będących wyrazem jednostkowego poczucia dobrostanu wynikającego z poziomu zadowolenia lub niezadowolenia z dziedzin życia, którym dana osoba przypisuje największe znaczenie (Diamond, Becker 1999). Duża zmienność i szeroki zakres możliwości, które ma każda starzejąca się osoba, skłaniają badaczy do opracowywania odrębnych koncepcji jakości życia i dobrostanu w starości różniących się między sobą zakresem składowych, źródeł i zmienności (Błachnio 2019). Postęp w rozumieniu starości, szczególnie tej dobrej, pomyślnej i optymistycznej sprawia, że poszukiwanie czynników, które pomimo przeżywanych kryzysów zapewniają człowiekowi poczucie wysokiej jakości życia, jest aktualne i potrzebne. Czego zatem dowiadujemy się od seniorów? Jakie zdarzenia z ich życia uznają oni za ważne i znaczące dla swoich biografii? Czy narracje seniorów mogą stanowić źródło wiedzy i podstawę do uczenia się z biografii Innych? 


\section{Krytyczne wydarzenia życiowe jako stymulatory rozwoju w dorosłości}

Maria Tyszkowa (1996) zauważa, że tym, co kieruje biegiem życia człowieka i stymuluje zmiany rozwojowe są różne formy działalności, czyli aktywność własna jednostki (człowiek jest aktywnym kreatorem zmian w swoim życiuํ) oraz tzw. zdarzenia krytyczne, które warunkują ciągłość owej aktywności oraz losów jednostki. Rozwój w dorosłości to ciąg zmian związanych „z prokreacją i wychowaniem, pracą i samorealizacją, motywacją osobistą i prospołeczną, kształtowaniem środowiska i uczestniczeniem w nim" (Oleś 2011: 12). W dorosłości szczególną rozwojową wagę mają osobiste decyzje podmiotu, w oparciu o które realizuje on niepowtarzalne (spersonalizowane) projekty biograficzne.

Kategoria krytycznych wydarzeń życiowych (critical events) opisuje wyjątkowe okoliczności życiowe. Według Heleny Sęk krytyczne wydarzenia życiowe (KWŻ) są „wzajemnym oddziaływaniem elementów w układzie podmiot-otoczenie powodującym stan niezrównoważenia, który jest stanem zwrotnym, krytycznym, wymagającym restrukturacji układu" (Sęk 1991: 32). Z reguły są to nagłe i niespodziewane zdarzenia, które zatrzymują jednostkę, wybijają ją z rytmu codziennego życia, z rutyny i wymagają zastosowania nowych sposobów radzenia sobie. 0 krytycznych wydarzeniach życiowych mówi się, że są to wydarzenia zmiany życiowej, przełomy, kamienie milowe. Nie są, jak można by przypuszczać, tylko negatywne. Są one przede wszystkim przełomowe i zawierają w sobie podwójną wartościowość: niosą ryzyko regresu lub zatrzymania rozwoju w sytuacji nieporadzenia sobie ze skutkami i następstwami doświadczanych okoliczności życiowych a jednocześnie stanowią szansę na rozwój i stają się przyczynkiem do autokreacji (por.: tamże: 32-33). Maria Beisert (1994) identyfikuje tzw. kryteria krytyczności na przykładzie rozwodu jako wydarzenia przełomowego w życiu systemu rodzinnego i jego członków. Ma ono destabilizujący charakter i obejmuje kilka kryteriów krytyczności.

Po pierwsze, wydarzenie życiowe, aby zyskało status wydarzenia krytycznego, musi wyodrębnić się $\mathrm{w}$ toku codziennych zdarzeń, ponieważ wiąże się $\mathrm{z}$ ważnymi dla człowieka wartościami. Jest więc znaczące emocjonalnie.

Po drugie, wydarzenie krytyczne jest potencjalnie dwuwartościowe. Dotyczy cenionych i emocjonalnie znaczących sfer funkcjonowania jednostki, która poprzez zmaganie się z tym wydarzeniem subiektywnie ocenia je jako pozytywne i negatywne. Dwuwartościowość wydarzeń krytycznych odnosi się także do uruchamianych przez osobę sposobów radzenia sobie z tym wydarzeniem i ich efektów. Mogą przyczynić się zarówno do rozwoju jednostki, jak i do jej regresu (por. Beisert 1994: 45).

\footnotetext{
1 Sformułowanie jest parafrazą tytułu artykułu Małgorzaty Kulety (2002): Człowiek jako kreator zmian w swoim życiu, w którym autorka prezentuje psychiczne i osobowościowe uwarunkowania gotowości do zmiany, a w szczególności powiązanie czynników motywacyjnych i zdolności kreacyjnych z możliwością satysfakcjonującego kierowania własnym życiem.
} 
Po trzecie, wydarzenie krytyczne ma ramy czasowo-przestrzenne. Jest ono zazwyczaj rozciągnięte w czasie (jego skutki mogą trwać wiele lat), obejmuje swoim zasięgiem kilka przestrzeni życia jednostek (np. rodzinną, zawodową) oraz odnosi się do różnych obszarów ich funkcjonowania (np. zdrowie fizyczne i psychiczne).

Po czwarte, wydarzenie krytyczne zmusza pomiot do zastosowania zupełnie nowych środków działania. Dotychczas stosowane strategie układania się podmiotu z otoczeniem zawodzą i należy poszukać nowych. 0 procesie, jego zakresie i tempie dyskutuje wielu badaczy (np.: Beisert 1994, 1995, 2000; Kübler-Ross 1998; Jelonkiewicz 1992). Ciekawą jest propozycja siedmiofazowego modelu Leoni Sugarman (2001: 144-148). Badaczka, adaptując model Barriego Hopsona (1981), opisuje proces zmagania się z przełomem życiowym, rozumiejąc go jako przejście (tranzycję) od starej tożsamości do nowej tożsamości.

Zaproponowane przez Sugarman fazy, to kolejne etapy, których pokonanie doprowadzić ma jednostkę do przebudowy dotychczasowej linii życia w taki sposób, by doświadczenie przełomowego wydarzenia stało się zasobem i wartością. Przedstawiają się one następująco:

- Brak mobilizacji (immobilization), znieruchomienie, osłupienie - jest to tak zwany okres szoku, kiedy „wydarzenie nie dociera do jednostki”, towarzyszy mu niedowierzanie i poczucie, że to, co się stało, nie może być prawdą.

- Reakcja, która uzależniona jest od nastroju, jaki towarzyszy wydarzeniu, oraz od jego okoliczności. Zdarzenie może mieć wartość dodatnią lub ujemną dla jednostki. W rezultacie może ona ujawniać podniecenie lub rozpacz.

- Zwątpienie w siebie, które jest często kontynuacją poprzedniej fazy. Pierwotnie (oryginalnie) nazywano tę fazę fazą depresji; jest to jednak, jak pisze Sugarman, pojęcie zbyt szerokie. Zwątpienie w siebie może przejawiać się lękiem, gniewem i złością, wahaniem nastroju: od gniewu do apatii (Sugarman 2001: 146).

- Ujawnienie emocji, wypuszczenie, pozostawienie za sobą (letting go) - w tej fazie pojawia się szansa dla osoby na wyjście z sytuacji traumatycznej w rozwojowej formie. Pozostawienie za sobą przeszłości to pogodzenie się z rzeczywistością, w przeciwnym razie rozwój jednostki zostaje zahamowany, a ona sama podtrzymuje w sobie przeszłość, nie podejmując nowych aktywności. Akceptacja nowego stanu rzeczy bywa trudna i burzliwa, zmaganie się z własną przeszłością, od której należy się uwolnić, często łączy się z przeżywaniem szeroko rozumianej żałoby po stracie (strata może odnosić się zarówno do osób, jak i wartości, idei itp.). Jest to również ważny moment, w którym nieszczęście i tragedia mogą zostać subiektywnie przewartościowane (w terapii systemowej moment ten określa się metaforą: „przemiany łzy w perłę"2). Ujawnienie emocji wymaga odwagi zerwania dawnych

2 Metaforą tą posługuje się także Nina Ogińska-Bulik (2013). 
więzi uczuciowych, wkroczenia w nieznaną przyszłość, w której nowe relacje jeszcze nie są nawiązane.

- Badanie, eksploracja (testing) nowych terenów aktywności. Po etapie rezygnacji z podtrzymywania w sobie przeszłości człowiek jest gotowy i zdolny do podjęcia poszukiwania oraz badania nowych dróg i sposobów działania, do dokonywania nowych wyborów. Jest to okres eksperymentalnego sprawdzania nowej tożsamości (por. Adamczak 1992).

- Poszukiwanie znaczenia i sensu (search of meaninig) przeżytych zdarzeń i włączanie ich do zestawu własnych doświadczeń. W tej fazie następuje świadoma próba refleksji, głębszego zrozumienia znaczenia zmiany w życiu. Proces ten bazuje na odzwierciedlaniu i myśleniu, które może doprowadzić do pełnego zrozumienia i subiektywnego usensownienia zmiany życiowej w miejsce patologicznego zatrzymania się na przeszłości (por. tamże).

- Integracja to etap, na którym proces przechodzenia przez cykl zmian może zostać uznany za zakończony. Przeżycia związane z zaistniałym wydarzeniem zostają włączone w przestrzeń życiową, a samo wydarzenie przestaje dominować. Cykl zmian, przez które człowiek przeszedł, zaczyna integrować się z doświadczeniem i strukturą osobowości oraz wzmacnia gotowość do radzenia sobie z dalszymi trudnościami i daje siły do przezwyciężania ich. Osiągnięta integracja może, ale nie musi, oznaczać poprawę funkcjonowania człowieka oraz zwiększenie jego potencjału rozwojowego (por. Kuryś 2010: 42-43).

Zmaganie się z okolicznościami życia, przejścia i tranzycje, dokonywanie wyborów oraz podejmowanie wysiłków autokreacyjnych służą budowaniu niezależności jednostki, a także jej biograficznej wyjątkowości i niepowtarzalności. Heliodor Muszyński (2002: 147-179), opisując walkę człowieka dorosłego z wpływami społecznymi, wyróżnia cztery mechanizmy personalizacyjne jako swoiste sposoby poradzenia sobie z konformistycznymi zachętami społecznymi. Są to: transakcje z okolicznościami życia, stawianie przed sobą i realizacja zadań życiowych, poszukiwanie i adaptacja wzorów osobowych oraz autokreacja. Każdy wymieniony mechanizm personalizacyjny może być postrzegany i doświadczany jako konflikt. Istotnym z punktu widzenia podjętych w tym opracowaniu rozważań jest mechanizm transakcji z okolicznościami życia. Polega on na konfrontowaniu pragnień i dążeń jednostki z rozmaitymi sytuacjami życiowymi (Kozielecki 1976: 534-565; Kuryś 2010: 33-46). Jednostka, pozostając w relacji z otoczeniem, w którym żyje, dokonuje ciągłych wartościowań, zawierających się w wyróżnionych przez Richarda Lazarusa (1986) transakcjach: wyzwania, straty i zagrożenia. Zgodnie z modelem Lazarusa dokonanie oceny pierwotnej w jednej ze wskazanych wyżej kategorii znaczeniowych implikuje konkretne sposoby reakcji w postaci odpowiednio podjęcia działania, załamania i ucieczki. Transakcje z okolicznościami życia stymulują do zmian o charakterze mentalnym, emocjonalnym i motywacyjnym, i pozwalają na wyznaczenie tzw. czasu psychologicznego (Oleś 2011: 21). 
Omawiane tu krytyczne wydarzenia życiowe można uznać za specjalny rodzaj okoliczności życiowych. Najczęściej nie są one wpisane w bieg ludzkiego życia, występują w sposób nagły i niespodziewany, a przez doświadczające jednostki są postrzegane jako znaczące, jako punkty zwrotne w ich życiu. Należy tu podkreślić, że o przełomowości wydarzenia nie świadczy sam fakt odnotowania go we własnej biografii, ale subiektywna jego interpretacja, nadanie mu znaczenia/dostrzeżenie w nim moderatora dotychczasowego sposobu własnego funkcjonowania. Takie przełomowe wydarzenie staje się zatem doświadczeniem.

Z psychologicznego punktu widzenia doświadczenie ujmuje się jako zespół informacji wpisanych w mózg, czyli śladów pamięciowych. Na całokształt doświadczenia człowieka składają się: 1) doświadczenie gatunkowe, przekazywane drogą dziedziczenia; 2) doświadczenie indywidualne, tj. ta część doświadczenia, którą jednostka wynosi z bezpośrednich kontaktów z otoczeniem i z różnych obszarów własnej w nim aktywności oraz 3) doświadczenie społeczne, przejmowane na drodze komunikacji interpersonalnej i przyswajania kultury, a więc w toku procesów socjalizacji i wychowania (Tyszkowa 1987: 3-4).

Wydaje się, że w szczególności doświadczenia indywidualne stanowią najsilniejszy stymulator rozwojowy. Dzięki nim człowiek uczy się własnych zachowań, reakcji na okoliczności życia, dokonuje bilansu zysków i strat, ma świadomość swoich mocnych i słabych stron, wie, co jest dla niego dobre, a co może mu zagrażać. Doświadczająca jednostka w biegu swojego życia nabywa wiedzy o samym sobie (Kuryś 2010: 16). I dzięki temu możliwe jest także uczenie się z tego typu doświadczeń, czyli tzw. uczenie się bezpośrednie, „tj. w trakcie życia, w sytuacjach organizowanych lub incydentalnych, związanych z realizacją zadań życiowych i podejmowanymi aktywnościami czy też ich zaniechaniem" (Dubas 2017: 64). Zatem, należy przypuszczać, że także takie okoliczności życiowe, które są potencjalnie prawdopodobne i wpisane w społecznie i kulturowo „zaprojektowany” bieg naszego życia (np. zawarcie związku małżeńskiego, urodzenie dzieci, śmierć rodziców), mogą stanowić dla doświadczających ich jednostek punkty przełomowe, gdyż wywołują zmiany w życiu i wymagają zastosowania nowych, nieznanych dotąd sposobów radzenia sobie. $\mathrm{W}$ tak poszerzonej optyce także te zdarzenia biograficzne nazwiemy krytycznymi wydarzeniami życiowymi, gdyż ich skutki i konsekwencje są tylko w ograniczonym zakresie przewidywalne, z pewnością jednak nie jest możliwe ich precyzyjne zaplanowanie. Poniżej przedstawiamy rodzaje zdarzeń życiowych wyodrębnionych z doświadczeń jednostki w biegu jej życia.

Pierwszym rodzajem zdarzeń odnotowywanych w biegu życia są tzw. zdarzenia normatywne, które odnoszą się do każdego człowieka w danej grupie wiekowej. Zdarzenia normatywne prowadzą do tzw. zmian uniwersalnych: wszyscy ludzie w określonym czasie swojej biografii doświadczają podobnych zdarzeń. Możemy 
zatem założyć, iż zmiany te są w dość dużym stopniu odporne na działanie czynników środowiskowo-kulturowych i moglibyśmy wskazać takie same zadania i kryzysy normatywne dla osób w ostatniej fazie rozwoju, bez względu na ich pochodzenie, miejsce zamieszkania czy status materialny.

Tabela 1. Charakterystyka rodzajów zdarzeń życiowych

\begin{tabular}{|l|l|l|}
\hline \multicolumn{1}{|c|}{ Charakterystyka } & \multicolumn{1}{|c|}{ Baltes i in. (1980) } & Bee (1994) \\
\hline $\begin{array}{l}\text { Odnoszące się do każdego człowieka } \\
\text { w danej grupie wiekowej }\end{array}$ & $\begin{array}{l}\text { zdarzenia normatywne } \\
\text { (z ang. normative age - graded } \\
\text { events) }\end{array}$ & $\begin{array}{l}\text { zmiany } \\
\text { uniwersalne }\end{array}$ \\
\hline $\begin{array}{l}\text { Zależne od grupy, do której jednostka } \\
\text { należy (generacyjnej, rodzinnej, } \\
\text { lokalnej, sąsiedzkiej) }\end{array}$ & $\begin{array}{l}\text { normatywne zdarzenia histo- } \\
\text { ryczne (z ang. normative history } \\
\text {-graded evenst) }\end{array}$ & $\begin{array}{l}\text { zmiany } \\
\text { wspólne }\end{array}$ \\
\hline $\begin{array}{l}\text { Indywidualne, losowe, ważne, unika- } \\
\text { towe, oddziałujące tylko na daną } \\
\text { jednostkę }\end{array}$ & $\begin{array}{l}\text { nienormatywne zdarzenia } \\
\text { życiowe (z ang. non normative } \\
\text { life events) }\end{array}$ & $\begin{array}{l}\text { zmiany } \\
\text { indywidualne }\end{array}$ \\
\hline
\end{tabular}

Źródło: opracowanie własne, Kuryś 2010: 14-15.

Kolejny, drugi rodzaj zdarzeń stanowią normatywne zdarzenia historyczne. Są typowe dla osób będących z jednej grupy, np. pokoleniowej. Wspólne przeżycia (będące najczęściej pochodną zdarzeń o charakterze społeczno-gospodarczym lub politycznym) pozwalają wyróżnić kohorty generacyjne. Normatywne zdarzenia historyczne prowadzą do tzw. zmian wspólnych (por. Kuryś-Szyncel 2017a).

Trzecim rodzajem zdarzeń są tzw. nienormatywne zdarzenia życiowe. W literaturze nazywane są zdarzeniami zmiany życiowej, przełomami życiowymi oraz krytycznymi wydarzeniami życiowymi (Filipp, Braukmann 1981; Sęk 1991; Adamczak 1992; Kuryś 2010; Krawczyk-Bocian 2013). Krytyczne wydarzenia życiowe (KWŻ) prowadzą do tzw. zmian indywidualnych.

Starość jest wyjątkowym okresem pod względem doświadczania przez jednostki krytycznych wydarzeń życiowych, ponieważ, co zostało już powiedziane, czas biograficzny i dystans, z jakiego seniorzy mogą oglądać bieg własnego życia, sprzyja wzrostowi liczby tzw. przełomów życiowych. Poza tym starość przynosi zdecydowanie większą liczbę strat osobistych niż to miało miejsce w poprzednich fazach życia.

Opowiadanie o tych zdarzeniach (doświadczeniach swojego życia, doświadczeniach przypominanych), które miały miejsce często w odległej przeszłości, oraz wysłuchiwanie tych opowieści przez innych (badaczy, czytelników) stwarza możliwość uczenia się pośredniego, czyli uczenia się biograficznego (por. Dubas 2017: 65). 


\section{Seniorzy wobec przełomów biograficznych - analiza wyników badań własnych}

Prezentowane poniżej rezultaty stanowią fragment wyników projektu przeprowadzonego w 2019 r. w województwie Kujawsko-Pomorskim. Badaniami objętych zostało 270 osób, dobór osób do badań był doborem celowym. Zależało nam na tym, by pozyskać narracje od osób dorosłych reprezentujących trzy pokolenia w obrębie danego systemu rodzinnego. Przyjęłyśmy za P. K. Olesiem (2011: 16), że „o granicach poszczególnych okresów w życiu konkretnego człowieka decyduje nie wiek biologiczny, choć nie można go oczywiście pominąć, ale rodzaj interakcji między osobą a środowiskiem". Uczynienie relacji rodzinnych kontekstem społecznym pozwoliło na wyłonienie trzech kohort osób badanych: dzieci we wczesnej dorosłości (wiek powyżej 20 lat); rodzice w średniej dorosłości (40-55 lat) oraz dziadkowie w późnej dorosłości (przedział 60-80 lat). W każdej z wyodrębnionych kohort znalazło się około 90 osób³.

Badania zostały przeprowadzone przez studentów II roku studiów stacjonarnych psychologii. Studenci otrzymali precyzyjne instrukcje oraz zostali przeszkoleni, jak przeprowadzać tematyczny wywiad biograficzny i badania kwestionariuszowe ${ }^{4}$. Zadaniem studentów było pozyskanie do badań osób z trzech przedziałów dorosłości - wczesnej, średniej i późnej. Możliwe było - dla osób chętnych - dokonanie badań autoetnograficznych dotyczących własnego systemu rodzinnego i ten scenariusz badań był preferowany.

Celem badań było sprawdzenie, czy w subiektywnym doświadczaniu szczęścia występuje odrębność właściwa kohorcie urodzeniowej i/lub transfer międzygeneracyjny jego wyznaczników ${ }^{5}$. $\mathrm{Z}$ tego względu zaplanowane zbadanie trzech pokoleń było istotne.

Prezentowane poniżej analizy odnoszą się do rekonstrukcji przełomowych zdarzeń w życiu badanych osób oraz sposobów radzenia sobie z nimi. Przełomy

\footnotetext{
${ }^{3}$ Ze względu na to, że analizy zebranego materiału narracyjnego są nadal w toku, nie można w tym momencie precyzyjnie i jednoznacznie określić liczby osób przynależnych do każdej kohorty oraz wskazać liczby kobiet i mężczyzn znajdujących się w każdej z wyróżnionych grup pokoleniowych. Wskazane wartości oznaczają liczbę osób, które wzięły udział w badaniu.

${ }^{4}$ Badania (wywiad oraz badanie kwestionariuszowe) odbywały się najczęściej w miejscu zamieszkania osób badanych, w uzgodnionym wcześniej terminie, tak by zapewnić osobom badanym komfort i poczucie bezpieczeństwa. Udział $\mathrm{w}$ badaniach był w pełni dobrowolny. Po uzyskaniu wszelkich wymaganych zgód i zapewnieniu o anonimowości oraz poinformowaniu o przebiegu badania, jego celu oraz sposobie wykorzystania pozyskanych danych rozmowy były rejestrowane przy użyciu nośników cyfrowych. Osoby badane zostały poinformowane o możliwości wycofania wyrażonych zgód na każdym etapie badania. Badacz przeprowadzał z osobą badaną tematyczny wywiad biograficzny. Pomiar obejmował ponadto pytania zamknięte stanowiące treść kwestionariuszy SWLS (Diener i in. 1985), KPJŻ (Straś-Romanowska i in. 2004) oraz drabinę Cantrila. Pełna dokumentacja zawierająca instrukcje przeprowadzenia wywiadu i badań kwestionariuszowych znajduje się do wglądu u autorek niniejszego artykułu. Materiały te zostaną również opublikowane w przygotowywanej publikacji zwartej.

5 To, czy i w jakim zakresie składowe subiektywnego poczucia szczęścia podlegają transferowi międzygeneracyjnemu, choć interesowało autorki, w tym artykule nie będzie szerzej dyskutowane.
} 
życiowe są traktowane jako punkty znaczące w biografiach trzech pokoleń. Rekonstrukcja tych wydarzeń ma pomóc w znalezieniu odpowiedzi na główne pytanie badawcze dotyczące przejawów poczucia jakości życia badanych osób (przede wszystkim seniorów). Możliwość dokonania porównań międzypokoleniowych stwarza sposobność uchwycenia istotnych biograficznie punktów, kamieni milowych, przełomów życiowych w rekonstruowanych biografiach.

Poniżej prezentujemy tylko wybrane fragmenty przeprowadzonych badań, odnoszące się do problematyki krytycznych wydarzeń życiowych. Stanowią one przykłady odpowiedzi na pytanie: Czy w twoim życiu były jakieś przełomowe, ważne dla ciebie wydarzenia?

Seniorzy w wieku 60 plus wskazują przede wszystkim na wydarzenia z obszaru osobistego, życia rodzinnego. Sporadycznie w ich narracjach ujawniają się zdarzenia z życia społecznego i zawodowego (np. udział w wydarzeniach politycznych, zmiana miejsca zamieszkania, np. przeprowadzka ze wsi do miasta, zmiana pracy) oraz te związane ze zdrowiem: choroby, wypadki. Najczęściej wskazywanym przez osoby badane wydarzeniem jest małżeństwo i urodzenie dzieci, zwłaszcza pierwszego dziecka. Dla osób będących dziadkami ważnym wydarzeniem jest pojawienie się na świecie wnucząt. Przyjrzyjmy się zatem najczęstszym narracjom:

Na pewno dużym, przełomowym wydarzeniem dla mnie było zawarcie związku małżeńskiego, następnie narodziny dzieci, później wnucząt (transkrypcja 6, Wywiad IV-4AL, mężczyzna, pokolenie dziadków).

Przełomowe, przełomowe, przełomowe. Małżeństwo i narodzenie się dzieci, i już (transkrypcja 3, 8MJ, kobieta, pokolenie dziadków).

No, to były takie wydarzenia, że wyszłam za mąż po prostu, urodziłam potem wspaniałe dwie córki. To było bardzo ważne w moim życiu właśnie, no i. Pomagałam też wychowywać wnuków. No, myślę, że, ślub ważny, tak samo, ale najważniejsze właśnie było, że zostałam mamą - że moje życie wtedy się musiało zmienić, bo musiałam sobie z wieloma sprawami radzić sama, bo mój mąż pracował przeważnie w delegacji zawsze był daleko, dzieci chorowały, no i w ogóle. Jakoś sobie z tym wszystkim radziłam i myślę, że je dobrze wychowałam na, na mądre i wspaniałe dziewczyny - i kobiety - które założyły swoje własne rodziny i są szczęśliwe raczej (transkrypcja 3, 16WT, kobieta, pokolenie dziadków).

Narratorzy wskazują na tradycyjne, normatywne następstwo zdarzeń w czasie i ujawniają typowy przebieg biografii rodzinnych od tzw. fazy preparentalnej rozpoczynającej się zawarciem związku małżeńskiego poprzez wypełnianie zadań rodzicielskich (faza parentalna), której istotnym punktem przełomowym jest oczywiście pojawianie się dzieci (szczególnie pierwszego), aż do fazy postparentalnej i wypełniania zadań małżeństwa emeryckiego, kiedy dla wielu osób sensem życia staje się opieka nad wnukami.

Zawarcie związku małżeńskiego rozpoczyna bieg życia systemu rodzinnego. Oznacza zmianę życiową, ale przez wiele osób z pokolenia dziadków postrzegane 
jest jako naturalna kolej rzeczy, a nawet swoista powinność. Jest też wyrazem najczęstszego projektu życiowego, realizowanego przez osoby z pokolenia, które weszło w dorosłość przed transformacją ustrojową w Polsce. Patrycja Guja, powołując się na ustalenia Philipova (2003), pisze, że proces zakładania rodzin do końca lat 80. XX w. w Polsce i Europie Środkowej odznaczał się m.in. „wczesnym i prawie powszechnym małżeństwem; ponad 90\% ogółu kobiet przynajmniej raz wyszło za mąż, a średni wiek zawarcia pierwszego małżeństwa wynosił 22-23 lata" (Guja 2016: 40).

Urodzenie pierwszego dziecka w rodzinie to wydarzenie, które wywołuje ogromne zmiany nie tylko w życiu kobiet i mężczyzn, ale całego systemu rodzinnego, jaki tworzą. Mają one charakter rozwojowy, ponieważ diada małżeńska przechodzi z fazy preparentalnej do fazy parentalnej, a przejście to wymaga zastosowania nowych, nieznanych dotąd sposobów radzenia sobie. Badani szczególnie mocno doświadczają zmiany w zakresie wolności osobistej i liczbie obowiązków. To rodzi $\mathrm{w}$ nich ambiwalentne stany emocjonalne: pojawia się radość, ale i lęk. Z kolei poczucie odpowiedzialności wiąże się z odczuwaniem zmęczenia i przeciążenia obowiązkami. Poniższe narracje ukazują opisany powyżej zakres i charakter zmian.

Myślę, że takimi momentem w moim życiu było urodzenie dzieci, zwłaszcza pierwszego dziecka. To było w pięćdziesiątym dziewiątym roku. Było ciężko, ponieważ nie było wtedy takich środków dostępnych. Lecznictwo było zupełnie inne. I dobrze je znałam bo pracowałam w szpitalu. Byłam młoda, bo miałam tylko dwadzieścia lat. (...) właściwie to byłam bardzo szczęśliwa, ale bałam się. Nie wiedziałam czy - czy sobie poradzę. Czekałam na to pierwsze dziecko bardzo. Jak na każde zresztą (transkrypcja 5, transkrypcja 303, kobieta, pokolenie dziadków).

No małżeństwo zmieniło całe życie bo nie dość, że jest się do kogo odezwać, to jest jeszcze o kogo się martwić, a jak się dzieci narodziły, to już odpowiedzialność. Niestety odpowiedzialność i wielka radość (transkrypcja 3, 8MJ, kobieta, pokolenie dziadków).

Przed no to wiadomo, swoboda można było sobie wszędzie jechać na wakacje, na wczasy, do koleżanek, z koleżankami się spotykać. A po to wiadomo: nieprzespane noce, stres, dzieci płaczące, kolki i tak dalej, i tak dalej (transkrypcja 6, WYWIAD III- /3KK/ BABCIA, kobieta, pokolenie dziadków).

Wcześniejsze, bo przeprowadzone w latach 2003-2004 przez Karolinę Kuryś (2010), badania pokazały, że kobiety i mężczyźni różnią się w ocenie wielkości i zakresu zmian, które towarzyszą urodzeniu się ich pierwszego dziecka. Większość kobiet uznaje, że jest to wydarzenie wprowadzające dużą, a nawet bardzo dużą zmianę w życiu. Średni wynik oceny wielkości zmian wyniósł w grupie kobiet $8^{6}$.

\footnotetext{
${ }^{6}$ Ocena dokonywana przez osoby badane na skali $0-10$, gdzie 0 oznacza brak zmian, a 10 bardzo duże zmiany.
} 
Z kolei dla mężczyzn przyjście na świat ich pierwszego dziecka nie stanowi aż tak znaczącej zmiany. Średnia ocen w przypadku badanych mężczyzn wyniosła 4 (por. Kuryś 2010: 109-115).

Pomimo faktu, że zarówno kobiety i mężczyźni mówią o swoim rodzicielstwie głównie w kategoriach wyzwania i spełnienia, to jednak dla kobiet macierzyństwo oznacza także często kryzys, przełom, natomiast dla mężczyzn ojcostwo to przede wszystkim obowiązek (por. tamże: 128-133).

Aktualne badania zdają się potwierdzać ten podział, szczególnie w odniesieniu do narracji mężczyzn. W pokoleniu dziadków również dominantą znaczeniową jest poczucie obowiązku. Oto przykład takiej narracji:

Oczywiście, że były. W siedemdziesiątym siódmym roku, w tysiąc dziewięćset siedemdziesiątym roku zawarłem związek małżeński z obecną twoją babcią Halinką (...). Później narodziny dzieci tak samo, no i więcej to po prostu nie pamiętam (...) Najważniejsze, tak. (...) No zmiany takie wprowadziły, że poczułem się już taki bardziej dorosły no i bardziej obowiazkowy po prostu (transkrypcja 6, WYWIAD IV - 4KK /DZIADEK/, mężczyzna, pokolenie dziadków).

Wzorzec realizacji ról rodzinnych oraz sposobów radzenia sobie z wynikającymi z przypisanych im społecznie i kulturowo powinnościami i zadaniami podlega transmisji międzypokoleniowej ${ }^{7}$. Zarówno dla mężczyzn seniorów, jak i dla młodych ojców ich własne ojcostwo to przede wszystkim sprawdzian z dorosłości rozumianej jako obowiązek i odpowiedzialność. Mężczyźni częściej niż kobiety, mówiąc o przełomach życiowych, odnoszą się w pierwszej kolejności do obszaru zadań i obowiązków związanych z aktywnością społeczno-zawodową (np. podjęcie pracy, zmiana pracy, znaczący awans), na drugim miejscu umieszczają zdarzenia związane z życiem rodzinnym. Wydaje się, że pozyskanie odpowiedniego statusu ekonomicznego jest dla mężczyzn warunkiem do założenia rodziny.

Było kilka wydarzeń przełomowych $\mathrm{w}$ moim życiu pierwszym przełomowym zdarzeniem w moim życiu było, jak zrealizowałem swoje marzenia w końcu i dostałem się na studia medyczne, które ukończyłem. Drugim moim (...) Drugie przełomowe zdarzenie w moim życiu, to było, kiedy poznałem i zobaczyłem po raz pierwszy (a w zasadzie drugi) moją

\footnotetext{
7 Badania nad znaczeniem i zakresem transmisji międzypokoleniowych mają swoje źródło w teorii społecznego uczenia się i były prowadzone na gruncie pedagogiki i psychologii praktycznie od lat 70 . XX w., szczególnie intensywnie po tym jak Albert Bandura w latach 60. XX w. przeprowadził wraz ze współpracownikami słynny eksperyment z lalką Bobo, dowodząc, że dzieci uczą się zachowań agresywnych od dorosłych. W Polsce, zwłaszcza w latach 90. XX w., poddawano licznym analizom transmisyjny charakter przekazu wzorców zachowań, np. agresywnych (Rostowska 1996), sposobu realizacji ról społecznych i rodzinnych (np. Sitarczyk 1993, 1994) oraz, bardziej współcześnie, wartości i postaw (np. Jezierska-Wiejak 2013). Aktualnie dużą wagę przykłada się do transmisji międzypokoleniowej także jako źródła wiedzy oraz uczenia się biograficznego (np. Muszyński 2014). W naszych badaniach wątek transmisji międzypokoleniowej jest istotny, ale ze względu na ograniczoną objętość niniejszego opracowania oraz jego tematykę nie będzie w tym miejscu rozwijany.
} 
małżonkę i to było ba-, przełomowe bardzo zdarzenie w moim życiu, ponieważ wtedy założyliśmy wspólnie rodzinę i po wieloletnich staraniach urodziły nam się wspaniałe dzieci, które były trzecim przełomowym zdarzeniem w moim życiu. (trankrypcje 4JG TWB (1), mężczyzna, pokolenie dziadków)

Wskazywane przez osoby badane jako przełomowe wydarzenie w ich życiu urodzenie pierwszego dziecka jest przykładem krytycznego wydarzenia życiowego, gdyż spełnia wszystkie wymienione wcześniej kryteria krytyczności.

Po pierwsze jest dla młodych dorosłych wydarzeniem nowym i dotyczy nadrzędnych wartości życiowych, tj. rodziny. Oznacza także, jak pokazują przytoczone narracje, utratę cenionych wartości, do których wiele osób zalicza wolność (swobodę i niezależność) osobistą. Przyjście na świat pierwszego dziecka wiąże się z pojawieniem się nieznanych dotąd stanów emocjonalnych i uczuć, takich jak miłość macierzyńska i ojcowska, ale także ciągła obawa i troska o dzieci. Po drugie, przyjście na świat dziecka wymusza zmiany w codziennym życiu, wymaga przeorganizowania czasu pracy, form odpoczynku i spotkań z przyjaciółmi. Zmiany w trybie życia wymagają zastosowania skutecznych sposobów radzenia sobie z ich skutkami. Po trzecie, urodzenie dziecka, szczególnie pierwszego, jest potencjalnie dwuwartościowe. Jedna z cytowanych powyżej narratorek mówi: „Niestety odpowiedzialność i wielka radość". Może przyczynić się do rozwoju osobistego, ale także, w efekcie nieporadzenia sobie ze zmianami (przeciążenia obwiązkami), zagrozić zatrzymaniem tego rozwoju, popadnięciem w apatię, uaktywnieniem się stanów depresyjnych. Po czwarte, wydarzenie krytyczne, takie jak urodzenie pierwszego dziecka, ma swoje ramy czasowo-przestrzenne. Rozgrywa się w dość jasno określonej przestrzeni życia rodzinnego i jest rozciągnięte w czasie. W perspektywie filozoficzno-egzystencjalnej można powiedzieć, że doświadczenie związane z przyjściem na świat dziecka (szczególnie pierwszego) trwa od urodzenia (od momentu uzyskania informacji o ciąży) aż do śmierci (dziecka lub rodzica).

Potwierdzenie i podsumowanie powyższych rozważań znajdujemy w poniższej narracji. Jedna z najstarszych narratorek, 83-letnia kobieta na pytanie o przełomowe wydarzenie w jej życiu odpowiada: „Urodzenie dziecka” i dalej, poproszona przez badacza o opisanie życia przed tym wydarzeniem i po nim oraz o wielkość zmian, które to zdarzenie wywołało w życiu, narratorka tak mówi:

(Przed) Było smutne, cały czas z myślami, żeby to dziecko mieć (...) (Po) Bardzo szczęśliwa, bardzo szczęśliwa, no i cieszyłam się tym dzieciątkiem, dla mnie był cały/całe przeżycie, cały skarb (...) Bardzo dużo zmian, dziesiątka (...) No że one dały mi, jakby motor do życia, coś takiego. Sens życia, nie. (transkrypcja 3JG TWB (1), kobieta, pokolenie dziadków)

Warto zauważyć, że analiza narracji osób badanych w opisywanym projekcie przynosi niewiele danych na temat sposobów radzenia sobie z przełomem życio- 
wym, jakim jest przyjście na świat pierwszego dziecka. Jest to z pewnością efekt sposobu postrzegania ról rodzicielskich oraz miejsca i znaczenia samej rodziny w biegu życia człowieka, szczególnie przez pokolenie dziadków. Jak już wcześnie powiedziałyśmy, w Polsce do końca lat 80. XX w. małżeństwo było typowym projektem życiowym. Przeważał model rodzin z dwójką dzieci, a urodzenie pierwszego dziecka było wczesne i powszechne. Charakteryzując proces zakładania rodzin w tym okresie, P. Guja pisze: „udział kobiet, które miały przynajmniej jedno dziecko wynosił ponad 90\%, przy czym pierwsze dziecko rodziło się ok. 1 roku po zawarciu małżeństwa" (Guja 2016: 40).

Kolejnym, frekwencyjnie najczęściej wskazywanym przez badanych seniorów wydarzeniem przełomowym jest śmierć bliskiej osoby (rodziców, rodzeństwa, współmałżonków oraz dzieci). Zgodnie z klasyfikacją Thomasa Holmesa i Richarda Rahe’a (1967) śmierć bliskiej osoby (męża/żony/partnera/partnerki) jest zdarzeniem obarczonym największym stresem życiowym. W starości śmierć bliskiej osoby jest przykładem zdarzenia życiowego, którego specyfikę można oksymoronicznie nazwać: „normatywną nienormatywnością” (por. Kuryś-Szyncel 2017a: 50). Jest to zdarzenie z jednej strony nienormatywne, gdyż jest ono (mimo różnych towarzyszących mu okoliczności, np. choroby) nieprzewidywalne, pozostające poza kontrolą człowieka, nieoczekiwane i nieplanowane; z drugiej strony staje się ono w tej fazie życia paradoksalnie normatywnym zdarzeniem, gdyż każdy, kto dożył wieku sędziwego, z całą pewnością doświadczył lub doświadczy straty bliskich.

Doświadczenie straty rodziców jest wpisane w bieg życia człowieka i ze względu na perspektywę czasową i obiektywny (biologiczny) wiek życia seniorzy najczęściej mają już to doświadczenie w swoich wspomnieniach, doświadczyli go w przeszłości. Poniżej prezentujemy kilka wybranych narracji odnoszących się do doświadczeń związanych ze śmiercią najbliższych, obrazujących jednocześnie proces zmagania się z tym wydarzeniem.

Natomiast śmierć mamy była dla mnie wielkim szokiem bo byłyśmy ze sobą blisko związane i po prostu brakowało i brakuje mi do dzisiaj tej osoby. A śmierć mojego taty poprzedzona chorobą, przykuciem go do łóżka i w tym samym podjęcie przeze mnie pracy zawodowej po długim okresie przerwy, to było bardzo trudne zadanie. Natomiast śmierć rodziców, no śmierć mamy spowodowała, że stałam się opiekunką chorego ojca i musiałam, mama była moją jakby to powiedzieć, bardzo mi pomagała w życiu, w wychowaniu dzieci w tym, i bez niej było mi dużo ciężej, natomiast po śmierci ojca poczułam się po prostu sierotą, zwyczajnie, brakowało mi rodziców. (transkrypcja 3, 7JM), kobieta, pokolenie dziadków)

Śmierć bliskiej osoby zawsze wywołuje u osób osieroconych szok i niedowierzanie bez względu, czy jest poprzedzona długotrwałą chorobą, czy w sposób naturalny przychodzi w podeszłym wieku. W literaturze przedmiotu wyodrębnia się kilka faz zmagania się ze stratą, jaką jest śmierć bliskiej osoby. Douglas A. Rund i Jeffrey C. Hutzler (1993, cyt. za Ostoja-Zawadzka 1999: 92) opisują pięć faz od 
„uczuciowej anestezji” będącej efektem doświadczanego szoku, poprzez ujawnienie emocji w postaci „szlochu i protestu”, kolejno „dezorganizację” z licznymi psychosomatycznymi objawami, jak np. napady lęku, paniki, zaburzenia snu, brak apetytu, po kończącą proces copingu „reorganizację”. Autorzy mówią także o piątej fazie, w przypadku nietypowego przebiegu żałoby, kiedy osoba osierocona nie radzi sobie ze stratą, czyli o tzw. „patologicznej żałobie” (por. Ostoja-Zawadzka 1999: 92). Wszystkie etapy mają swój sens i znaczenie, a kolejne przechodzenie służy powolnemu uwalnianiu się od przeszłości i budowaniu pozytywnych wizji rzeczywistości na przyszłość. Poradzenie sobie ze stratą i rozwojowe przejście przez proces żałoby kończy się reorganizacją. Ta rozpoczyna się około pół roku po stracie i oznacza stopniowe powracanie do normy, której warunkiem jest akceptacja śmierci i nieodwracalnej nieobecności bliskiej osoby jako realnego faktu. Zgodnie z opisanym wcześniej modelem tranzycji L. Sugarman przejście przez przełomowe wydarzenie powinno zakończyć się nadaniem znaczenia doświadczeniu oraz integracją. Pełne zrozumienie i subiektywne usensownienie zmiany życiowej sprawiają, że przeżycia związane z zaistniałym wydarzeniem zostają włączone w przestrzeń życiową, a samo wydarzenie przestaje dominować. Cykl zmian, przez które człowiek przeszedł, zaczyna integrować się z doświadczeniem i strukturą osobowości oraz wzmacnia gotowość do radzenia sobie z dalszymi trudnościami i daje siły do przezwyciężania ich. Doskonałym przykładem integracji trudnego doświadczenia nagłej utraty bliskiej osoby oraz uruchomienia procesu uczenia się z własnych doświadczeń (nadania sensu i wyciągnięcia wniosków na przyszłość) jest poniższa narracja:

No i od tego momentu (śmierci brata, przypis K.K.S., A.B.) stwierdziłam, że trzeba trochę inaczej sobie życie poukładać, tak w każdej chwili ktoś może zginąć, coś się może stać, trzeba inaczej spojrzeć na życie (...) Przewartościować sobie, tak, znaleźć sobie priorytety które są najważniejsze bo dla każdego człowieka są inne, ja mam swoje, a ktoś może mieć inne, mi one się zmieniły. (transkrypcja 3, 10ML), kobieta, pokolenie dziadków)

Wstępne analizy wskazują, iż znaczące, przełomowe wydarzenia biograficzne dotyczą przestrzeni życia rodzinnego i są najczęściej związane z jego inicjowaniem. Momenty odchodzenia i przybywania stanowią, zgodnie z systemowym rozumieniem rodziny, jej dynamikę. Odpowiadają za utrzymywanie systemu w dynamicznej równowadze napięć. Trevor R. Hadley i inni badacze (1974, cyt. za: Simon, Stierlin 1998: 42) stwierdzili istnienie znaczącego związku między pojawieniem się zaburzeń a rozwojowym kryzysem przybycia (narodziny) lub odejścia (śmierć, separacja) członka rodziny. Według Hilla i Matessicha (1979, cyt. za: Beisert 2000: 94) rozwój rodziny ograniczony jest historią pojawiania się i wzrastania dzieci (por. Kuryś 2011: 47). 
Emocjonalna dynamika życia rodzinnego oscyluje między radością z przychodzenia nowych członków rodziny oraz smutkiem spowodowanym odejściem starych członków. Poniższa narracja, będąca kolejnym przykładem odpowiedzi seniorów na pytanie o wydarzenia przełomowe w życiu, obrazuje tę dynamikę. Jest to zarazem dobry przykład zmiany w zakresie obowiązków i przejęcia odpowiedzialności wynikających z naturalnego biegu życia rodziny.

No oczywiście jak w każdym życiu niespodziewana pierwsza to śmierć mojej mamy. Urodzenie syna a po ośmiu latach urodzenie upragnionej córki no i oczywiście urodzenie się wnuka i wnuczki (...) No oczywiście, że wywołały zmiany. Bardzo radosne gdyż syn obdarzył mnie wnukiem i prawnuczką, a moja córka ukochaną wnuczką. A niespodziewane, to była śmierć mojej mamy, przełomem w moim dorosłym życiu, bo zdałam sobie sprawę, że dalsze życie mojej rodziny zależy już tylko ode mnie. (transkrypcja 6, WYWIAD III (3KP), kobieta, pokolenie dziadków)

Z perspektywy lat, w narracjach retrospektywnych badani seniorzy wskazują, że najbardziej przełomowe zdarzenia w ich życiu to założenie rodziny (zawarcie związku małżeńskiego, narodziny pierwszego dziecka) oraz straty związane ze śmiercią najbliższych krewnych. Perspektywa temporalna i faktyczny upływ czasu biograficznego mogłyby sugerować, że w wypowiedziach osób badanych pojawią się odniesienia do normatywnych zdarzeń historycznych i zmian wspólnych. Dotychczasowe analizy narracji nie ujawniły wielu takich treści. Seniorzy nie wspominają sytuacji społeczno-politycznej, bardzo rzadko nawiązują np. do zmian systemowych w Polsce, a jeśli takie wątki ujawniają się w wypowiedziach, to stanowią one kontekst dla doświadczeń osobistych (prywatnych). Wyjątek stanowi narracja 60-letniego mężczyzny, który w swojej narracji na temat wydarzeń przełomowych odnosi się tylko do swojej sytuacji zawodowo-społecznej:

No przede wszystkim wybór szkoły to jest studiów był bardzo trudny na studiach po pierwszym miesiącu studiowania strajk całego całej uczelni trzynastego grudnia (...) już stan wojenny no i później praca po studiach, pierwsza praca. Po trzech latach funkcja dyrektora. Później zostanie radnym no i przełomowy wybór na wójta gminy X (nazwa własnazakodowano, przypis K.K.S, A.B) (...) to znaczy najprawdopodobniej najważniejsze to jest wybór na stanowisko wójta. Bardzo ludzie dużo mi zaufali, funkcję tę piastowałem przez dwanaście lat i myślę, że dobrze, no ale oczywiście przychodzi taka chwila gdzie, w nowych wyborach po dwunastu latach zostałem radnym powiatowym, natomiast już wybory wójta nie przeszedłem. Natomiast uważam, że funkcję swoją pełniłem bardzo dobrze, gmina nie była zadłużona gmina postępowała, a mieszkańcy żyli w niej zadowoleni. (transkrypcja WS3- mężczyzna, brak danych dotyczących pokolenia).

Ten sam mężczyzna w dalszej części wywiadu (która nie podlegała w tym opracowaniu omówieniu) na pytanie o ważne i znaczące osoby w jego życiu tak odpowiada: „No wiadomo dom, rodzina, żona, dzieci”. 


\section{Podsumowanie}

Zaprezentowany powyżej fragment wyników badań, podjęte próby konceptualizacyjne oraz poczynione analizy i refleksje pozwalają stwierdzić, że perspektywa temporalna uruchamiana przez osoby stare ujawnia odbiorcy ważną „mądrość życiową", dotyczącą priorytetów życiowych. Jesteśmy świadome tego, że uzyskane wyniki (a nawet same badania) są wybiórcze, bo dotyczą - ze względu na podjęty problem badawczy - tylko osób mających rodziny. Z pewnością ciekawe wnioski dotyczące doświadczanych przełomów życiowych można byłoby wysnuć z badań nad seniorami, którzy pozostawali całe życie sami (tzn. nie założyli rodziny). Przeprowadzone analizy mają charakter jakościowy i pomimo powtarzalności pewnych obserwacji i wniosków na ich podstawie formułowanych rezultatów nie należy dowolnie generalizować. Możemy jednak założyć, że te zdarzenia, które są postrzegane u schyłku życia jako ważne i znaczące dla naszych biografii, są prawdopodobnie najważniejszymi zdarzeniami egzystencjalnymi w ogóle. Stąd wniosek, który mógłby mieć wydźwięk wychowawczy: zewnętrzne okoliczności życia, czas historyczny, uwarunkowania geopolityczne jakkolwiek odgrywają ogromną rolę w naszej codzienności, nie odciskają się na naszych biografiach tak silnym piętnem jak nasze życie osobiste. Prywatne, jednostkowe wybory, relacje w związkach intymnych, budowanie trwałych, satysfakcjonujących więzi i relacji to te zdarzenia i okoliczności życiowe, które wydają się istotnie znaczące dla naszego życia. Jednakże, co warto podkreślić, sposób doświadczania codzienności oraz radzenia sobie z ulokowanymi w niej zdarzeniami o charakterze przełomowym jest zależny od wyróżnionych wyżej zewnętrznych okoliczności życia, jak czas historyczny czy warunki geopolityczne. Zaobserwowana w dotychczas przeprowadzonych analizach materiału badawczego niewielka ilość danych na temat sposobów radzenia sobie z przełomami życiowymi przez współczesnych seniorów (na przykładzie przyjścia na świat pierwszego dziecka i śmierci bliskiej osoby) może być efektem okoliczności zewnętrznych, które towarzyszyły tym zdarzeniom i co za tym idzie, powszechnego (popularnego) ze względu np. na czas historyczny sposobu postrzegania ról rodzicielskich oraz miejsca i znaczenia samej rodziny w biegu życia człowieka w pokoleniu osób urodzonych w Polsce tuż po zakończeniu II wojny światowej - w latach 40. i 50. XX w.

\section{Bibliografia}

Adamczak M. (1992) Krytyczne zdarzenia życiowe i radzenie sobie z nimi - wybrane zagadnienia w: Elementy psychologii klinicznej, B. Waligóra (red.), T. 2, Poznań, Wydawnictwo Naukowe UAM, s. 40-73.

Baltes P. B., Reese H. W., Lipsitt L. P. (1980) Life-span developmental psychology, „Annual Review of Psychology", 31, s. 65-110. 
Bee H. L. (1994) Life-span development, New York, Harper Collins College Division.

Beisert M. (1994) Rozwód jako wydarzenie krytyczne w cyklu rozwoju rodziny, „Problemy Rodziny", nr 2, s. 41-45.

Beisert M. (1995) Psychologiczna sytuacja kobiet rozwiedzionych w: Studia kobiece z psychologii, filozofii i historii, J. Miluska, E. Pakszys (red.), Poznań, Wydawnictwo Naukowe UAM, s. 51-68.

Beisert M. (2000) Rozwód. Proces radzenia sobie z kryzysem, Poznań, Wydawnictwo Fundacji „Humaniora”.

Błachnio A. (2006) Autor siebie w trzeciej fali cywilizacyjnej, Bydgoszcz, Wydawnictwo UKW.

Błachnio A. (2011) Człowiek autorski w erze globalizacji, Bydgoszcz, Wydawnictwo UKW.

Błachnio A. (2017) Jakość i strategie życia w starości w: A. Błachnio, K. Kuryś-Szyncel, E. Martynowicz, A. Molesztak, Psychologia starzenia się i strategie dobrego życia, Warszawa, Difin, s. 61-80.

Błachnio A. (2019) Potencjał osób w starości. Poczucie jakości życia w procesie starzenia się, Bydgoszcz, Wydawnictwo Uniwersytetu Kazimierza Wielkiego.

Bugajska B. (2015) Dziewiq̨ta faza w cyklu życia - propozycja rozszerzenia teorii psychospołecznego rozwoju E. H. Eriksona, „Biblioteka Gerontologii Społecznej”, nr 1 (9), s. 19-36.

Diamond R., Becker M. (1999) The Wisconsin Quality of Life Index: a multidimensional model for measuring quality of life, „Journal of Clinical Psychiatry”, 60 (suppl. 3): 29-31.

Diener E., Emmons R. A., Larsen R. J., Griffin S. (1985) The Satisfaction with Life Scale, „Journal of Personality Assessment”, 49 (1): 71-75.

Dubas E. (2011) „Uczenie się z biografii Innych” - wprowadzenie w: Uczenie się z biografii Innych, E. Dubas, W. Świtalski (red.), Łódź, Wydawnictwo Uniwersytetu Łódzkiego, s. 5-11.

Dubas E. (2017) Uczenie się z własnej biografii jako egzemplifikacja biograficznego uczenia się, „Nauki i Wychowaniu. Studia Interdyscyplinarne”, nr 1 (4), s. 63-87.

Erikson E. H. (1959) Identity and life cycle: selected papers, New York, International University Press.

Erikson E. H. (1997) Dzieciństwo i społeczeństwo, tłum. P. Hejmej, Poznań, REBIS. 
Filipp S.-H., Braukmann W. (1981) Verfahren zur Erfassung kritischer Lebensereignisse Eine Übersicht, w: Kritische Lebensereignisse, S.-H. Filipp (red.), München, Urban und Schwanzenberg: 92-103.

Gilhooly M. L., Gilhooly K. J., Phillips L. H., Harvey D., Brady A., Hanlon P. (2007) Realworld problem solving and quality of life in older people , British Journal of Health Psychology", 12: 587-600.

Guja P. (2016) Wpływ transformacji ustrojowej na model rodziny w Polsce, „Studia Ekonomiczne. Zeszyty Naukowe Uniwersytetu Ekonomicznego w Katowicach", nr 290, s. 39-50.

Hadley T. R., Jocob T., Milliones J., Caplan J., Spitz D. (1974) The relationship between family developmental crisis and the appearance of symptoms in a family member, „Family Process”, 13: 207-214.

Havighurst R. J. (1972) Human development and educations, New York, McKay.

Hill R., Mattessich P. (1979) Family Development Theory and Life-Span Development w: Life-Span Development and Behavior, P. B. Baltes Jr., O. G. Brim (red.), New York -San Francisco-London, Academic Press, 2: 161-204.

Holmes T. H., Rahe R. H. (1967) The social readjustment rating scale, „Journal of Psychosomatic Research", 11: 213-218.

Jelonkiewicz I. (1992) Radzenie sobie rodziców z chorobq dziecka, „Nowiny Psychologiczne", nr 4, s. 101-108.

Jezierska-Wiejak E. (2013) Polska rodzina jako międzypokoleniowa płaszczyzna transmisji wartości, „Wychowanie w Rodzinie”, t. VIII, nr 2, s. 285-299.

Konieczna-Woźniak R. (2015) Aktualne/zapomniane tematy gerontologii - mądrość ludzi starszych i jej rola w życiu ludzi młodych, „Biblioteka Gerontologii Społecznej”, nr 1 (9), s. 51-64.

Kozielecki J. (1976) Czynności podejmowania decyzji w: Psychologia, T. Tomaszewski (red.), Warszawa, PWN, s. 534-565.

Krawczyk-Bocian A. (2014) Doświadczanie zdarzeń krytycznych: narracje biograficzne dorosłych dzieci alkoholików, Bydgoszcz, Wydawnictwo UKW.

Kübler-Ross E. (1998) Rozmowy o śmierci i umieraniu, Poznań, Media Rodzina.

Kuleta M. (2002) Człowiek jako kreator zmian w swoim życiu w: Człowiek wobec zmiany. Rozważania psychologiczne, D. Kubacka-Jasiecka (red.), Kraków, Wydawnictwo Uniwersytetu Jagiellońskiego, s. 21-37. 
Kuryś K. (2010) Urodzenie pierwszego dziecka jako wydarzenie krytyczne w życiu kobiet i mężczyzn, Kraków, Oficyna Wydawnicza „Impuls”.

Kuryś K. (2011) System rodzinny wobec zmian rozwojowych, Poznań, Wydawnictwo Naukowe UAM.

Kuryś-Szyncel (2017a) Diagnoza starości w Polsce w: A. Błachnio, K. Kuryś-Szyncel, E. Martynowicz, A. Molesztak, Psychologia starzenia się i strategie dobrego życia, Warszawa, Difin, s. 39-60.

Kuryś-Szyncel (2017b) Międzygeneracyjny mentoring w: A. Błachnio, K. Kuryś-Szyncel, E. Martynowicz, A. Molesztak, Psychologia starzenia się i strategie dobrego życia, Warszawa, Difin, s. 137-159.

Laubovie-Vief G. (1990) Wisdom as integrated throught: historical and developmental perspective w: Wisdom: It's nature, origins, and development, R. J. Sternberg (red.), New York, Oxford University Press: 52-183.

Lazarus R. S., (1986) Paradygmat stresu i radzenia sobie, „Nowiny Psychologiczne”, nr 3-4, s. 2-39.

McAdams D. P., de St. Aubin E., Logan R. L. (1993) Generativity among young, midlife, and older adults, „Psychology and Aging ”, 8: 221-230.

Muszyński H. (2002) Socjalizacja - personalizacja - wychowanie w: Wychowanie. Profilaktyka. Resocjalizacja. W poszukiwaniu doskonalszych systemów w skali makro i mikro, J. Sowa, E. Piotrowski, J. Rajmon (red.), Rzeszów, Podkarpacki Ośrodek Doskonalenia Nauczycieli, s. 86-98.

Muszyński M. (2014) (red.) Międzypokoleniowe uczenie się, Łódź, Wydawnictwo Uniwersytetu Łódzkiego.

Obuchowski K. (2000) Człowiek intencjonalny, czyli o tym, jak być sobq, Poznań, REBIS.

Obuchowski K. (2005) The subjects' revolution, Łódź, WSHE.

Ogińska-Bulik N. (2013) Pozytywne skutki doświadczeń traumatycznych, czyli kiedy „łzy zamieniają się w perły”, Warszawa, Difin.

Oleś P. (2011) Psychologia człowieka dorosłego, Warszawa, Wydawnictwo Naukowe PWN.

Ostoja-Zawadzka K. (1999) Żałoba w rodzinie w: Wprowadzenie do systemowego rozumienia rodziny, B. de Barbaro (red.), Kraków, Wydawnictwo Uniwersytetu Jagiellońskiego, s. 91-96. 
Ożarowski W. (2011), Ustalenie przydatności Popperowskiej zasady falsyfikacji do oceny koncepcji osobowości autorskiej, „Horyzonty Psychologii”, nr I (1), s. 101-126.

Pietrasiński Z. (1990) Rozwój człowieka dorosłego, Warszawa, Wiedza Powszechna.

Pietrasiński Z. (2001) Mądrość, czyli świetne wyposażenie umysłu, Warszawa, Wydawnictwo Naukowe SCHOLAR.

Pietrasiński Z. (2008) Ekspansja pięknych umysłów: nowy renesans i ożywcza autokreacja, Warszawa, Wydawnictwo CIS.

Rostowska T. (1996) Transmisja międzypokoleniowa $w$ rodzinie $w$ zakresie zachowań agresywnych, „Przegląd Psychologiczny”, nr 1/2, s. 177-186.

Rund D. A., Hutzler J. C. (1993) Psychiatric emergencies associated with death. Emergency psychiatry, London, The C.V. Moshby Company.

Schalock R. L. (2004) The concept of quality of life: what we know and do not know, „Journal of Intellectual Disability Research", 48 (3): 203-216.

Sęk H. (1991) Procesy twórczego zmagania się z krytycznymi wydarzeniami życiowymi a zdrowie psychiczne w: Twórczość i kompetencje życiowe a zdrowie psychiczne, H. Sęk (red.), Poznań, Wydawnictwo Naukowe UAM, s. 30-41.

Simon F., Stierlin H. (1998) Słownik terapii rodzin, tłum. M. Przylipiak i in., Gdańsk, Gdańskie Wydawnictwo Psychologiczne.

Sitarczyk M. (1993) Transmisja międzypokoleniowa postaw rodzicielskich. Doniesienie z badań, „Problemy Rodziny”, nr 6, s. 37-41.

Sitarczyk M. (1994) Postawy rodzicielskie w percepcji dwóch pokoleń. Podobieństwa i różnice, „Problemy Rodziny”, nr 6, s. 31-34.

Staudinger U. M., Dörner J., Mickler C. (2005). Wisdom and personality w: A handbook of wisdom. Psychological perspective, R. J. Sternberg, J. Jordan (red.), Cambrige, Cambrige University Press: 191-219.

Straś-Romanowska M., Oleszkowicz A., Frąckowiak T. (2004), Charakterystyka Kwestionariusza Poczucia Jakości Życia, Wrocław, Instytut Psychologii UWr.

Sugarman L. (2001) Life-span development. Frameworks, accounts and strategies, New York, Psychology Press.

Tyszkowa M. (1987) Doświadczenie, kultura i rozwój psychiczny jednostki, Poznań, Wydawnictwo Naukowe UAM. 
Tyszkowa M. (1996) Pojęcie rozwoju i zmiany rozwojowej w: M. PrzetacznikGierowska, M. Tyszkowa, Psychologia rozwoju człowieka. Zagadnienia ogólne, Warszawa, PWN, s. 45-56.

Zalewska A. (2003) Dwa światy. Emocjonalne i poznawcze oceny jakości życia i ich uwarunkowania u osób o wysokiej i niskiej reaktywności, Warszawa, Wydawnictwo SWPS „Academica”.

\section{Źródła internetowe}

http://citeseerx.ist.psu.edu/viewdoc/download?doi=10.1.1.598.8643\&rep=rep1\&ty pe=pdf [dostęp: 5.03.2020].

Philipov D. (2003) Major Trends Affecting Families in Central and Eastern Europe, Major trends affecting families: (a background document) http://citeseerx.ist.psu.edu/ viewdoc/download?doi=10.1.1.598.8643\&rep=rep1\&type=pdf [dostęp: 5.03.2020. 